\title{
PSEUDO-PLATONIC IMMORTALITY: AXIOCHUS AND ITS POSTERITY IN HUMANISM
}

\author{
José María Zamora Calvo \\ Universidad Autónoma de Madrid, Madrid \\ jm.zamora@uam.es
}

\begin{abstract}
The aim of this article is to trace the influence of Axiochus, an apocryphal text attributed to Plato, on Humanism. The dialogue, which belongs to the literary genre of "consolation", addresses the theme of contempt of death and the immortality of the soul. The jurist Pedro Díaz de Toledo (1410/15 - 1466) translated it into Spanish in 1444 from a Latin version entitled De morte contemnenda, which Cencio de' Rustici had translated eight years earlier, probably from the Greek codex provided by Joannes Chrysoloras, the Vaticanus gr. 1031. For his part, the humanist Beatus Rhenanus $(1485-1547)$, the owner of five editions, revised and corrected in detail the text of a translation by Rudolf Agricola, proposing a number of amendments and changes that would appear in the Basel edition printed by Adam Petri in 1518 .

KeYWORDS: Axiochus, immortality of the soul, consolation, Pedro Díaz de Toledo, Beatus Rhenanus.
\end{abstract}

From Antiquity to the Renaissance, Axiochus, a spurious dialogue about contempt of death and the immortality of the soul, occupied an important position. In 1518, at least two editions of this dialogue translated by Rudof Agricola were published. In the middle of the 15th century, Pedro Díaz de Toledo translated "Un libro llamado Fedrón" into Spanish, dedicated to the Marquis of Santillana, from a Latin version translated in Bologna by Cencio de' Rustici between 1436 and 1437 . This text, however, does not correspond to the translation of Plato's Phaedo, but to the pseudo-Platonic Axiochus. For his part, Beatus Rhenanus of Sélestat used a

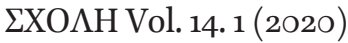

www.nsu.ru/classics/schole
(C) José María Zamora Calvo, 2020 DOI:10.25205/1995-4328-2020-14-1-38-56 
collection of Neoplatonic texts published by Aldo Manuzio in 1497, which contained a version of Axiochus. For certain Renaissance readers, fear of death could be overcome not only through Christianity, but also and especially by Plato's teachings on the immortality of the soul.

\section{An apocryphal text on the immortality of the soul, attributed to Plato}

The pseudo-Platonic Axiochus is a brief and attractive work written in a careful style, which provides the reader with a consolatio mortis, a series of arguments in defence of the immortality of the soul and a myth that includes a suggestive description of the Netherworld. ${ }^{1}$ We can presume, without being able to establish a precise date, that this dialogue was composed around the end of the 4 th century or beginning of the 3rd century BC. The text, which brings together in an eclectic manner the arguments of different schools, originated in the Academy and falls within the consolatory tradition, which explains not only its relationship with Phaedo and the Apology, but also with Cicero's Tusculan Disputations. ${ }^{2}$ The central theme (skopos) is that, if the soul disappears, there is no need to fear death because it becomes a release from human suffering and calamity.

This dialogue takes its name from Axiochus, an Athenian citizen, uncle of Alcibiades and father of Cleinias, ${ }^{3}$ who appears in the dialogue with Socrates, the musician Damon and Charmides. Socrates recounts that he was walking along the banks of the Ilissos river on his way to Cynosarges ${ }^{4}$ when Cleinias came out to meet him in the company of his lover Damon, the musician, and Charmides, son

${ }^{1}$ Cf. Bernabé 2013, 140-143. From among the contemporary editions and translations of this spurious dialogue, we highlight Hershbell 1981, with text by Joseph Souilhé and annotated translation; and the recent by Männlein-Robert, Schelske, Feldmeier, Grosse, Lohmar, Nesselrath, Poplutz 2012. This paper benefited from the support of two Spanish R\&D projects: Acis\&Galatea H2015/HUM-3362 and HAR2017-83613-C2-2-P, and is part of the activities of the UAM Research Group: "Influences of Greek Ethics on Contemporary Philosophy" (Ref. F-O55).

${ }^{2}$ Erler (2005, 81-95) shows the philosophical propaedeutic nature of Axiochus through the study of the child's metaphors in the adult and consolatory argumentation as therapy for the soul. On the inclusion of Apology as source, see Joyal 2005, 97-102.

${ }^{3}$ See Plato, Euthydemus 274b, 275a.

${ }^{4}$ According to Beghini $(2016,3-12)$, the reference to the Cynosarges at the beginning and end of Axiochus does not allude to the founder of the Cynicism school of thought, Antisthenes (c. $444-365 \mathrm{BC}$ ), but to the existence of a necropolis in the location, corroborated by archaeological and literary sources. This exegesis, in keeping with the theme of pseudo-Platonic dialogue, appears in the Latin translation by Cencio de' Rustici in the 15th century, probably from a lost source that testified to the existence of the $\mathrm{Cy}$ nosarges cemetery. 
of Glaucon and uncle of Plato. Cleinias expresses his concern for his father, Axiochus, who, gravely ill, is having difficulty coming to terms with his imminent death, and requests Socrates' presence to reassure him. By the time they arrive at his bedside, the terminally ill patient has recovered some strength, but continues to lament his imminent demise. To console him, Socrates begins a dialogue with the dying man with the intention of convincing him that death should not be feared, but rather desired, as if it were a release.

The theme of this dialogue seems to adopt the two alternatives on death that Socrates proposed after his conviction, as Plato mentions in his Apology: (1) he who has died does not exist and, therefore, cannot have any awareness of anything; or, (2) for the soul, death is a change, a move from one place to another. ${ }^{5}$

The dialogue is structured into two parts, preceded by an introduction (364a365c) and followed by a conclusion (372a).

In the first part, to persuade Axiochus that it is wrong to be distressed over losing his life, Socrates uses three arguments: According to the first of them $(365 \mathrm{~d}-$ $366 \mathrm{~b}$ ), the body is only a source of misfortunes and miseries for human existence; consequently, the end of life means passing from an ill state to a good one. The second argument $(366 \mathrm{~b}-369 \mathrm{~b})$, supported by an oration by the sophist Prodicus of Ceos (c. $470-390 \mathrm{BC}$ ), concludes that, as nobody, not even those engaged in political activity, is happy with their fate, the possibility that death provides of being released from any kind of life is neither contemptible nor regrettable. In the third argument ( $369 \mathrm{~b}-\mathrm{c})$, also borrowed from Prodicus, he argues that death cannot affect the living, because they still exist, nor the dead, because they no longer exist and, therefore, do not feel anything. ${ }^{6}$

The second part begins with a fourth argument (37ob-e) that focuses on the happiness of the soul after death, and ends with the myth told by the Persian magus Gobryas (371a-372a), which he narrates to support the preceding thesis and which thoroughly describes the place where souls rest after death. All souls are immortal, but while the righteous will eternally enjoy a happy and joyous exist-

\footnotetext{
${ }^{5}$ Cf. Plato, Apology 4oc.

${ }^{6}$ Dorion (2009, 370-371, and 538, n. 37) classifies this testimony as a dubious or apocryphal text attributed to Prodicus, since the subjects it addresses seem to be borrowed from various philosophers belonging to different schools of the 4th century BC, such as the academic Crantor, the Cynic Crates and Epicurus.

On the pessimistic discourse of Prodicus (Axiochus $366 \mathrm{~d}-369 \mathrm{~b}$ ), which tries to show that misery and suffering afflict man from childhood to old age, see Kerferd, Flashar 1998, 6o-63. In particular, on the first part of the list of the miseries that affect young people, according to the summary presented by Socrates of the "declamation" ( $\dot{\varepsilon} \pi \hat{\delta} \delta \varepsilon \xi \xi \zeta)$ that Prodicus pronounces in the house of Callias (Axiochus 367a1), see Beghini 2017, 270-273.
} 
ence, the unjust will forever have to endure suffering and tribulation. In the conclusion (372a), Axiochus, encouraged by the words of Socrates, changes from being afraid of death to desiring it because he is convinced that he is going to go to a better place.

The therapeutic dimension of Socrates in this pseudo-Platonic dialogue approaches the conception of the Hellenistic schools. Indeed, Axiochus comes from the heart of the academic consolation tradition, in which the Epicurean echoes are an attempt to adapt it to the spirit of the Hellenistic period. ${ }^{7}$ The "consolation" genre became a literary form with Crantor of Soli (c. $335-275$ BC), a disciple of Xenocrates in the Academy and first commentator on Plato's Timaeus, author

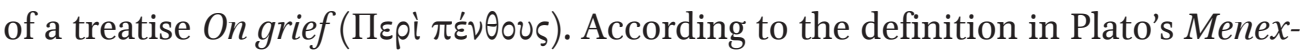

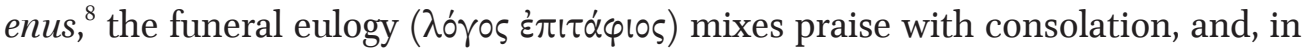
this genre, Aristotle's dialogue Eudemus (or On the soul), a tribute written in memory of his friend who died in $354 \mathrm{BC}$, can be included. This literary genre was also used by Cicero (Tusculan Disputations I and III), Seneca (Consolation to Marcia and Consolation to Polybius) and Plutarch (Consolation to his wife and Consolation to Apollo). Thus, the dialogue, whose spurious nature is beyond doubt, belongs, from a literary and philosophical point of view, to the Hellenistic consolation tradition, ${ }^{9}$ interweaving narrative, argumentation and myth in its dramatic action.

\section{The Spanish translation by Pedro Díaz de Toledo}

The jurist and man of letters Pedro Díaz de Toledo was born between 1410 and 1415, probably in Seville, into an influential Spanish family of Jewish converts. ${ }^{10}$ At the beginning of the 1430s, he began to study law at the University of Valladolid, finishing his studies on 12 September 1438 at the University of Lleida, where he acquired thorough training in civil and canon law. After obtaining his doctorate in law, on 15 October 1440, he was appointed appeals judge ("Alcalde mayor") and presided over the Royal Council under the direction of the crown prince. Subsequently, the following year, he acquired the position of high court judge ("Oidor de Audiencia") and Referendary. Between 1442 and 1446, while exercising his

\footnotetext{
${ }^{7}$ Cf. Tulli 2005, 255-271.

${ }^{8}$ Cf. Plato, Menexenus $236 \mathrm{e}$.

${ }^{9} \mathrm{Cf}$. Erler 2012, 100.

${ }^{10}$ Pedro Díaz de Toledo was the grandson of María de Toledo and nephew of the rapporteur of John II of Castile, Fernando Díaz de Toledo, father of Pedro Díaz de Toledo y Ovalle, future bishop of Málaga, of whom he was first cousin and with whom he should not be confused. See Sanz Fuentes 2014, 381-406; and see also Herrero Prado 1998, 110114; and Fernandes 2016, 6o-72.
} 
functions in these positions, he was commissioned by King John II of Castile to translate and gloss an apocrypha by Seneca, transmitted under the title of Proverbs, intended for the education of the crown prince, the future King Henry IV." Without entertaining the slightest suspicion about its authenticity, Díaz de Toledo considered this work of moral philosophy extraordinarily useful for the education of the future monarch.

In 1453, Díaz de Toledo was a member of a council of twelve doctors who tried and condemned Álvaro de Luna, Constable of Castile, in Valladolid. By 1459, alongside his surname, he bore the title of "Lord of Olmedilla" and, the following year, he retired to his residence in Alcalá de Henares, where he died in $1466 .{ }^{12}$ His remains were laid to rest in the parish church of Santa María (former chapel of San Juan de los Caballeros or Letrán) in this city, whose Oidor Chapel was built at

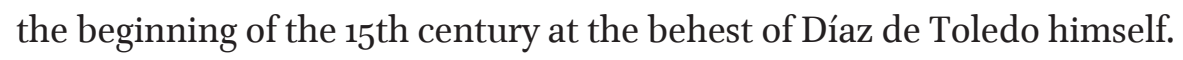

Axiochus, which at the time was believed to have been written by Plato, was translated into Spanish by Díaz de Toledo during the Christmas season of 1444, from an intermediate text, the Latin version of the Greek text of the dialogue translated by Cencio de' Rustici some eight years earlier. ${ }^{13}$ The incipit of the man-

${ }^{11}$ From Pedro Díaz de Toledo's mid-15th century translation and gloss of the apocrypha by the Córdoba-born philosopher, Proverbia Senecae, under the title Proverbios de Séneca, the following 15 th-century manuscripts are preserved: four in the National Library of Spain, with catalogue number Ms. 18066, Ms. 9964, Ms. 6724 and Ms. 8188, which also contains translations by Alonso de Cartagena; four in the Library of the Monastery of San Lorenzo de El Escorial: S-II-10, N-II-7. N-III-9, N-III-10 (the latter, probably the oldest, dated to before 146o); two in the Library of the Royal Palace of Madrid: Ms. II/92 and Ms. II/614 (which also includes the translation into Spanish of the Latin text of the Proverbs); one manuscript in the Library of the University of Salamanca: Ms. 1848; and another manuscript in Barcelona in the Library of Catalonia: Ms. 980.

On the manuscript tradition, see Blüher 1969, 111-155. n. 104; Round 1972; Riss 2005. Similarly, the printed tradition of the translation of the Proverbs of Seneca by Pedro Díaz de Toledo is extensive. From among the editions of the incunable period: in Zamora 1482 by Antonio de Centenera; in Saragossa 1491 by Juan Hurus; in Seville 1495 by M. Ungut and E. Polono; in Toledo 1500 by Pedro Hagenbach; in Seville 1500 by J. Pegnitzer and M. Herbst. After this date, it is printed in Seville 1512, 1528 and 1535 by Jacobo Cromberger; in Medina del Campo $155^{2}$ and 1555 by Adrian de Ghemart; in Antwerp $155^{2}$ by Jean Steelsius. On this printed tradition, see Blüher 1969, 111-155, n.105; and see also Roldán Donoso 2015,115 , n. 4 , and 116, n. 5 .

${ }^{12}$ At this time, at the service of the Bishop of Toledo, Alfonso Carrillo, cousin of the Marquis of Santillana, he composed the Glosas a la Exclamación e Querella de la Gouernagión.

${ }^{13}$ Cf. Hankins 199o, Vol. I, 95-98. 
uscript, acquired by the Biblioteca Nacional de España (BNE) in 2012, with catalogue number Ms. 15113, mentions the recipient, "su singular señor yñigo lopes de me[n]doça" the future Marquis of Santillana, as Lord de la Vega, which dates the translation to before 8 August 1445, the date on which John II of Castile bestowed on him the title of Marquis of Santillana and Count of Real de Manzanares, and, indeed, according to the foreword by Díaz de Toledo, he began working on it at the end of $1444 .{ }^{14}$

During the reign of John II (1406 - 1454), Castile began to emerge from its isolation with respect to the rest of Europe. From 1439, in particular, Spanish translations were positively influenced by Italian humanism. As González Rolán, Moreno Hernández and Saquero Suárez-Somonte point out, ${ }^{15}$ during this period, the challenge was to incorporate or, at any rate, explore both the Latin translations of Greek works and the original translations by Italian humanists.

However, with the support of patrons such as the Marquis of Santillana, Spanish versions of classical texts, from Homer to Aristotle and newly translated by the Italian humanists, took Latin as the primary source language. In opposition to Russell, who considers these Spanish versions as an attempt to medievalise and Christianise the ancient texts, rejecting the fundamental theses of humanism, ${ }^{16}$ González Rolán and Saquero Suárez-Somonte defend their humanist nature. ${ }^{17}$ Thus, in the Castile of the first half of the 15th century, Alonso de Cartagena, Alonso Fernández de Madrigal (El Tostado), Mosen Diego de Valera, Fernando del Pulgar, Juan de Mena, Juan Rodríguez del Padrón and the aforementioned Pedro Díaz de Toledo were "men of letters" (litterati), specialists in law or theology and experts in Latin.

In his Diálogo e razonamiento en la muerte del Marqués de Santillana, Díaz de Toledo manifested the close bond he maintained with this Spanish nobleman, for whom he translated many works and treatises from Latin into Spanish, by referring to him in its title. ${ }^{18}$ It was precisely from a Latin version by Leonardo Bruni

${ }^{14}$ In the foreword, Díaz de Toledo states that he translated the work in his house in Alcalá de Henares during a holiday, probably coinciding with the Christmas holiday of 1444, although he is not any more specific. On this point, see Round 1993, 100-101.

${ }^{15}$ González Rolán, Moreno Hernández, Saquero Suárez-Somonte 200o, 19-22 and 43-64.

${ }^{16}$ Cf. Round 1993, 16-125.

${ }^{17}$ Cf. González Rolán, Saquero Suárez-Somonte 2000, 163-164.

${ }^{18}$ In the BNE, a 15th century manuscript from the bibliographic collection of the Duke of Osuna and Infantado is preserved: Diálogo y razonamiento entre D. Fernando Ávarez de Toledo y el Dr. Pero Díaz, en la muerte del Marqués de Santillana, Ms. 10226. Incipit/Explicit: "Comiença el dialogo e su rasonamiento. Conde. Doctor a tiempo soes demostrar el amor que sienpre obistes al marques” (h. $5 \mathrm{v}$ ). “... porque desde aqui digamos 
$(1370-1444)$ that he translated Plato's Phaedo. ${ }^{19}$ In this same manuscript appears the translation of De beata vita by Augustine of Hippo, ${ }^{20}$ which links the problem of the immortality of the soul with the Christianisation of Plato. This aspect, which highlights the important connection that was made between Augustine and Plato, represents a key point for the reconstruction of the history of Augustinianism in the Spanish culture of the second half of the $15^{\text {th century. }}{ }^{21}$

In the manuscript preserved in the Bibliothèque nationale de France $(\mathrm{BnF})$, Ms. Esp. $458,{ }^{22}$ the translation does not, however, correspond to Plato's Phaedo, but to the pseudo-Platonic dialogue Axiochus, which in another manuscript preserved in the BNE, is dedicated to the Marquis of Santillana. ${ }^{23}$ As González Rolán and Saquero Suárez-Somonte point out, both the title, Fedrón instead of Fedón, and the inclusion of this dialogue instead of Axiochus is probably due to the Latin codex used by Díaz de Toledo to make the Spanish translations of both dia-

con el salmista david. Et benediciones dabit legis lator ibimus de virturite in virtutem ut videamus deus deorum in sion. Amen deo gracias. Explicit feliciter" (h. 89). We have an edition by Paz y Meliá 1892, 240-36o. On this work, see Cherchi 1992.

${ }^{19}$ BNE Ms. VITR/17/4. Tratados varios, which includes: Platón. Fedón (93 h.), from the library of the Duke of Osuna and Infantado: "[Introducción al libro llamado Fedrón, traducido por Pero Díaz de Toledo]". Incipit/Explicit: "De la inmortalidad del alma diversos actores” (h. 1). “... E quanto a esto asaz es dicho e entremos ya a su interpretacion” (h. 5). "Echecrates, tu Fedron fueste" (h. 5). "... con quienes nos conversamos e contractamos" (h. 59). Note on illustration: Initial in h. 1, which represents Socrates drinking hemlock, and in h. 6o, unfinished.

In addition to the cited edition of Round (1993), on the translation contained in the manuscript, see Grespi, 1992 37, 98 and 208.

${ }^{20}$ Augustine of Hippo, De beata vita. Incipit: "Varon muy humano et de grand virtud" (h. 6o).

${ }^{21}$ See Villacañas Berlanga 2010, 1-2.

${ }^{22}$ BnF Ms. Esp. 458. Physical description: (1) "Libro de Johan Bocaçio florentino, poeta laureado, el qual se intitula de los montes e rios e selvas." Spanish translation of the Liber de montibus, silvis, fontibus de Giovanni Boccaccio. (2) "Basilio de la reformacion de la anima." (3) Spanish translation of Plato's Axiochus by Pedro Díaz de Toledo. Year of acquisition: 1884. Relationship: http://archivesetmanuscrits.bnf.fr/ark:/12148/cc35o69j

About this manuscript, see Morel-Fatio 1892, Notice 683; and see also Avril, Aniel, Mentré, Saulnier, Zaluska 1983, 130-131.

${ }^{23}$ BNE Ms. 23245. Physical description: 8 h. Incipit/Explicit: "Segund dise Aristotiles en el terçero libro de sus ethicas ..." (h. 1). "... por passear donde fuy llamado et vine fasta aqui. Aqui termina el libro de Platon llamado Fedron ... como la muerte non es de temer. Deo gratias" (h. 8v). Source of acquisitions: Purchase: Pontes Maps, Madrid, 2013. Provenance note: Exlibris of Joaquín María Abaurre. 
logues. ${ }^{24}$ Thus, if we take as reference the codex kept in the Library of Cathedral at Burgo de Osma, ${ }^{25}$ which includes three works (tria opera Platonis) (Phaedo, Phaedrus and Axiochus), this theory would be corroborated.

This last apocryphal dialogue, however, is referred to with the term sermonem ${ }^{26}$ which would explain the fusion of the two previous titles Phaedonem and Phedrum, which would give the Spanish version Fedrón (Phae + drum).

The codex of Burgo de Osma attributes to Leonardo Bruni the Latin translation from the Greek text of the three works, including the sermo. However, Leonardo Bruni only translated the first two works, Phaedo and Phaedrus, but not Axiochus. The translator of this pseudo-Platonic dialogue (then still attributed to Plato) was the humanist Cencio de' Rustici (c. 1390 - 1445), a classmate of Bruni and a member of the papal curia, ${ }^{27}$ who, like him, learned the Greek language in Florence attending lessons taught by the Byzantine diplomat Manuel Chrysoloras. ${ }^{28}$ Between 1436 and 1437, when he was accompanying the papal retinue in Bologna, Cencio de' Rustici produced his Latin version, entitled De morte contemnenda, probably from the Greek codex provided by Joannes Chrysoloras, the Vaticanus gr. $1031 ;{ }^{29}$ and dedicated the translation to the recognised patron and bibliophile, Cardinal Giordano Orsini, who was suffering from a serious illness that would lead to his death the following year, $1438 .^{30}$

Of the Latin version of Axiochus, in addition to the above-mentioned Spanish translation by Díaz de Toledo, only one printed edition and thirty eight manuscripts are preserved, among which is the one held by the Library of the Cathedral at Burgo de Osma (Ms. 124), to which we have previously referred. This manu-

${ }^{24}$ Cf. González Rolán, Saquero Suárez-Somonte 200o, 168.

${ }^{25}$ Library of Cathedral at Burgo de Osma, Ms. 124 (s. XV). Incipit: "Continet hoc volumen tria opera Platonis, nempe Phaedonem, sive librum de immortalitate animorum, Phedrum, in quo poetices vis et natura describitur et sermonem de contemnenda morte. Omnia autem ex graeco in latinum sermonem translata sunt opera Leanardi Bruni Aretini". Phaedo's translation of Leonardo Bruni, with preface and letter to Niccoli (h. 77r-98r); Phaedrus' translation of Bruni, with preface and argument (h. $101 \mathrm{r}-109 \mathrm{v})$; Axiochus' translation of Cencio de'Rustici, with prefaces to Giordano Orsini and Velleius.

Cf. Orcajo 1929, 211; and Hankins 199o, Vol. I, 676-676.

${ }^{26}$ Cf. González Rolán, Saquero Suárez-Somonte 2000, 168-169.

${ }^{27}$ See Hankins 199o, Vol. l., 45, n. 33; and see also Männlein-Robert, Schelske, Feldmeier, Grosse, Lohmar, Nesselrath, Poplutz 2012, 39.

${ }^{28}$ Between 1397 and 1399 Manuel Chrysoloras teaches Greek in Florence. See Celenza 2007, 74-75.

${ }^{29}$ Cf. Belli 1954, 448-449.

${ }^{30}$ See Hankins 1990, Vol. 1, 82-83; Erler 2005, 81-82. 
script includes a letter of referral from Cencio de' Rustici to a friend of his called Velleius, whose identity has never been determined. ${ }^{31}$

The dialogue is known and recognised as a cure and medicine to combat the fear of death, and Cencio de' Rustici's translation, from then on, became his most admired work, contributing in a decisive way to the revival of Plato's work, although from its apocryphal aspect.

In tune with the humanist circle to which he belonged, Cencio de' Rustici resorted to a classic model, extracted from the pseudo-Platonic Axiochus, to replace the terrible representations of death and final judgment conveyed by contemporary preachers. ${ }^{32}$ The Latin translation retains the same skopos as its original Greek: to serve as consolatio mortis. In this regard, Cencio de' Rustici was enthralled by the Greek text, especially with the therapeutic aspect of Socrates' discourse, which attempted to console the dying Axiochus.

Thus, when Cencio de' Rustici translated Axiochus, he dedicated it to a terminally ill patient, Cardinal Orsini. Díaz de Toledo, for his part, to combat the fear of death and even show contempt for it, dedicated it to the future Marquis of Santillana, Íñigo López de Mendoza, fourteen years before his death and then in full possession of his faculties. For this reason, he did not reproduce the consolatory discourse present in Cencio de' Rustici literally, but adapted and interpreted it "in Renaissance style", ${ }^{33}$ attempting to answer a civic ethics question typical of his time: why certain virtuous men, although afraid of death, are willing to place it above their own lives, acting according to virtue and for the good of their own country.

Not only is there a Christian way to overcome the fear of death following the precepts of the late Middle Ages, based essentially on an interpretation of the texts of Ars moriendi (c 1415 - 1450), but also a humanistic way, based on an interpretation of the works of classic Greek and Roman authors, especially certain dialogues by Plato, such as Phaedo, or attributed to him, such as Axiochus.

In the above-mentioned Diálogo e razonamiento en la muerte del Marqués de Santillana, written after 25 March 1458, the date of death of the Spanish nobleman, and commissioned by the Count of Alba, Fernando Ávarez de Toledo, cousin and good friend of the Marquis, Pedro Díaz de Toledo followed the same structure as Axiochus: Álvarez de Toledo, who plays the role of Cleinias, implores

${ }^{31}$ Cf. González Rolán, Saquero Suárez-Somonte 2000, 170-171.

${ }^{32}$ See Hankins 1990, Vol. 1, 84-85.

${ }^{33}$ According to González Rolán and Saquero Suárez-Somonte (2000, 174-175), Díaz de Toledo, in line with the Renaissance conception, assigns a meaning to death fully. From this perspective, it connects with the proposal that Leonardo Bruni collects in his Laudatio funebris Jahannis Strazae, 1428. 
Díaz de Toledo, who plays the character of Socrates, to attempt to console the Marquis of Santillana, who, seriously ill, playing in this case the role of Axiochus, awaits irremediable death. In the Dialogue, Díaz de Toledo also incorporates words and phrases from his translation of Axiochus, ${ }^{34}$ enriching the literary work with this lexical and architectural interconnection.

\section{Axiochus in the Humanist Library of Beatus Rhenanus}

The humanist and philologist Beatus Rhenanus (whose real name was Beatus Bild), was born on 22 August 1485 in Schlettstadt (now Sélestat, Alsace). Belonging to a family originally from Rhinau, his father, Anton Bild, who was known as "Rhinower", was a butcher, and later elected to the offices of "Statmeister" in 1499 and "Schultheiss" in 1506. Motherless from the early age of two, his father sent him to study at the Latin school of Sélestat, where he excelled as a pupil of Crato Hoffmann and Jérôme Gebwiler. ${ }^{35}$ From the age of 15 to 18 , Rhenanus dedicated himself to the study of literary works, mainly on grammar and rhetoric, by recognised Italian and German humanists, acquired by his father for that purpose.

In 1503, probably on the advice of Gebwiler, he moved to Paris to continue his education at the university. During his studies, which were mainly devoted to logic, physics, metaphysics and Aristotle's ethics, he was greatly influenced by Jacques Lefèvre d'Etaples (c. 1455 - 1536) and Charles de Bovelles (c. 1475 1566). ${ }^{36}$ During this time, he also worked as a proofreader in the office of the printer Henri Estienne, where he acquired the skills of philologist and literary critic. After obtaining bachelor and master's degrees in Paris, he returned to Sélestat in 1507 and regularly spent time in Strasbourg, where he met Jakob Wimpfeling, Johann Geiler von Kaysersberg and Sébastien Brant, and worked in the printing house of Mathias Schurer, with whom he became friends.

In 1511, Rhenanus moved his residence to Basel to attend the Greek courses taught by the Dominican friar from Nuremberg, Johannes Cuno. ${ }^{37}$ During this

\footnotetext{
${ }^{34}$ Cf. González Rolán, Saquero Suárez-Somonte 2000, 179-181.

${ }^{35}$ The Humanist Library of Sélestat (BHS) retains the school notebook of Beatus Rhenanus (1498 /1499), with catalogue number: BHS MSo5o.

${ }^{36}$ Cahier d'étudiant de Beatus Rhenanus à l'Université de Paris, corresponding to the 1504/1505 academic year, BHS MSo58. "Commentaires d'Aristote par Lefèvre d'Etaples: Logique, Physique, Métaphysique”, ff. 9-11. On this topic, see Faye 1995; and see also Faye, Ancey 1995, 139-142.

${ }^{37}$ Johannes Cuno (c. 1462/1463 - 1513), a Dominican friar from Nuremberg, chose Basel because of its printing presses, such as that owned by Amerbach, for whom he
} 
time, he worked as a proofreader in the offices of the printers Johann Amerbach and Johann Froben, and met Erasmus of Rotterdam (1466 - 1536), of whom he became a great friend, scientific adviser and publishing representative. In 1519, due to the illness of his father and until his death the following year, Rhenanus lived between Basel and Sélestat, the city where he settled permanently in $15^{26}$ and devoted himself entirely to literary activities. In 1531, the Basel printing house Froben published his only original work, Rerum Germanicarum libri tres, and between 1540 and 1541, it published the first edition of the works of Erasmus, in nine volumes, preceded by a biography. Upon his death in Strasbourg on 20 July 1547, Rhenanus bequeathed his personal library to his native city, ${ }^{38}$ where his remains rest in St. George's Church.

According to the catalogue of the Bibliothèque Humaniste of Sélestat (BHS), drawn up by Walter, among the incunabula and 16th-century prints that Rhenanus acquired before 1518 , we find practically no direct reference to Plato. ${ }^{39}$ The founder of the Academy is absent from both the incunabula that we preserve and those that have disappeared. ${ }^{40}$ From after 1518 , there are only two works: Calcidius' translation of and commentary on Plato's Timaeus (1520) and the Latin translation of the complete works of Plato by Marsilio Ficino (1433 - 1499), revised by Simon Grynaeus (1532). However, we have two collections, attributed to Xenocrates - disciple of Plato and successor to Speusippus as head of the Academy - which include a Latin version of the pseudo-Platonic dialogue Axiochus, produced by Ficino. ${ }^{41}$ The first collection, which includes texts by Iamblichus and

worked, and the wealth of Greek manuscripts preserved in the city's convent, inherited from Cardinal John of Ragusa (c. 1390/95-1443). On Cuno, see Saffrey 1971.

${ }^{38}$ The BHS currently holds 460 manuscripts (ancient and modern), 550 incunabula and around 2,500 printed books from the 16th century. Its collections include the extraordinary Rhenanus library, an exceptional example of a humanist collection preserved almost intact in its entirety. This library consists of 423 volumes, including 1,287 works and 41 manuscripts, distributed among various collections, to which must be added 33 ancient manuscripts and 255 letters written by the Sélestat humanist. In 2011, the Rhenanus library was listed in the UNESCO Memory of the World Register. On biography of Rhenanus and his library, see Meyer 1976; and Diu 2008.

${ }^{39}$ See Walter 1929, 165-2363; and see also Diu 2008, 49-52.

${ }^{40}$ Cf. Meyer, Petitmengin 1985; and Petitmengin 1989.

${ }^{41}$ Along with the Latin translation by Ficino of the treatise De morte (= Axiochus) attributed to Xenocrates, the treatise De religione christiana, also written by Ficino, was published in Strasbourg by the Johann Knobloch printing house in 1507. Rhenanus possessed a copy in his library, preserved with catalogue number: BHS K 1072a/WJ 1320. See Hirstein 2013, 55, n. 20, and 59, n. 34. 
Proclus, but not Plotinus, was published in Venice in 1497 by Manutius' press. ${ }^{42}$ The second, which includes the treatise On the resurrection by the Christian philosopher Athenagoras of Athens (2nd century AD) and the Latin translation of the Tablet of Cebes by the renowned Paduan Classical scholar Ludovicus Odaxius (Odasio), is an incunabula published in Paris whose year of publication is not known. ${ }^{43}$

The only Platonic dialogue that Rhenanus possessed in his library was a Latin version of Axiochus by the Dutch humanist Rudolf Agricola (1444 - 1485), published around 1502 in the Paris printing house of Alexandre Aliate (for Jodocus Badius) ${ }^{44}$

At the school of Cardinal Lemoine, during his student days in Paris, Rhenanus did not seem to devote himself to the "passionate" reading of Plato's dialogues. Instead, he welcomed with fervour the philosophical method derived from Aristotelianism. The Alsatian student was a loyal supporter of Lefèvre's Aristotelian programme, and he especially considered Plato "a threat to the Christian faith". ${ }^{45}$ At the end of his Exigua pluvia, written in 1505, Rhenanus placed Plato among those responsible, along with Alexander of Aphrodisias and Averroes, for what he called "the deadly destruction of Italy" in the Renaissance. ${ }^{46}$

Thus, in a letter sent to Lefèvre, his teacher in Paris, written on 29 May 1509 for the George of Trebizond's (1395 - 1486) Dialectic edition, which would be published that same year in Strasbourg by the Schurer printing house, he stated: "[Trebizond] shows by means of arguments that make it clear that Aristotle's own way of philosophising is much more in accordance with Christian piety than that of Plato (quam Platonis longe esse Christianae pietati)" (div. 7).

However, we note the absence of other works by Ficino, such as Theologia platonica de immortalitate animorum, written between 1469 and 1474 and published in 1482, which could be described as a summa on the immortality of the soul, and the Complete works, which appeared in 1484 .

${ }^{42}$ See Zehnacker 1997, 46, n ${ }^{\circ} 1278$.

${ }^{43}$ According to Zehnacker $\left(1997,129-130, n^{\circ} 263\right)$, this work was published in the Parisian printing house of Guy Marchant on 18 August 1498.

${ }^{44}$ Moreau $(1972,87)$, drawing on the manuscripts of Renouard, establishes this approximate date of 1502 and this place of publication for Axiochus Platonis. De contemmenda morte, translated by Rudolf Agricola (BHS K 822e/WJ 2044). Faye (2000, 44-45), however, proposes the year 1501, in Paris, in the printing house of Jean Petit, and Walter (1929), that of Wolfgang Hopyl in the same year. In addition, Rhenanus possessed another text of this translation in an anthology of works by Agricola, published in Antwerp, by Dirk Martens' press, in 1511 (BHS K 1182c/WJ 556).

\footnotetext{
${ }^{45}$ Faye 2000, 44.

${ }^{46}$ See Faye 1998, 432.
} 
Between 1518 and 1519, however, Rhenanus' philosophical interest experienced a profound change. Under the influence of Erasmus, who he had met in 1514, Rhenanus experienced a doctrinal transformation: he vindicated Plato, against Aristotle, and considered Platonic works as the best introduction to philosophia Christi. For Rhenanus, Platonic teaching conformed to Christianity. Thus, in the Maximi Tyrii philosophi platonici sermones edition, ${ }^{47}$ Rhenanus undertook to defend Plato against his critics: ${ }^{48}$ Adopting one of the theses of the founder of the Academy, he considered that the community of men, women, children and property presented by Plato in Book V of Republic, ${ }^{49}$ encouraged charity by suppressing the passions that promote envy for what others possess..$^{50}$ For Erasmus' friend, the sharing of all things coincides with Christianity.

In 1516, Rhenanus published through the Basel printing house Froben an anthology of three works: Aeneas of Gaza (c. 430/450 - 518), presented as Platonicus christianus, his dialogue De immortalitate animorum, deque corporum resurrectione; Athenagoras of Athens (2nd cent. AD), De resurrectione; and Sextus the Pythagorean (2nd cent. AD), author of sentences. In his foreword, Rhenanus rejects Pythagorean arguments about the immortality of the soul and palingenesis, and defends the resurrection of bodies..$^{51}$ That same year, the Alsatian humanist annotated Apuleius de Madaura's treatise De dogmate Platonis. ${ }^{52}$

The transformation experienced by Rhenanus was confirmed in 1518 with the publication of Axiochus, a dialogue attributed to Plato. Although the publication does not include the name of the Alsatian director of publications, Hirstein identifies the "printing model" (Druckvorlage) in the Humanist Library of his home town, Sélestat. ${ }^{53}$ The discovery of a "printing model", whether it be a manuscript or a book, allows us not only to determine its origin and provenance, but also to show the type of cooperation between the owner and the publishing house. The

47 Maximus of Tyre, Maximi Tyrii philosophi platonici sermones, Cosmas de Pazzis, Beatus Rhenanus, Ambrosius Holbein, Johann Froben, Urs Graf. Johann Froben, 1519 .

${ }^{48}$ See Trapp 2000, 151-171; and see also Faye 2000, 46.

${ }^{49}$ In Republic $\left(45^{1} \mathrm{e}-45^{2 \mathrm{a}} ; 455^{\mathrm{d}}-456 \mathrm{a}\right)$, Plato proposes equality between men and women, that the guardians of the State have no private property ( $458 \mathrm{c}-\mathrm{d})$, and the community of women and children (449d, 457c-e, 461e, 464a, 466c, 543a; cf. Laws 739c). As

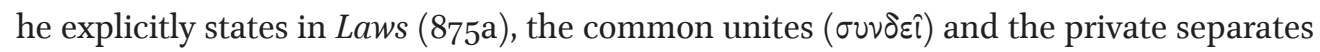
$(\delta\llcorner\alpha \sigma \pi \hat{\alpha})$, in the sense that it disperses or destroys cities.

${ }^{50}$ Cf. Horawitz, Hartfelder 1886, 134.

${ }^{51}$ Cf. Horawitz, Hartfelder 1886, 88.

${ }^{52}$ See Faye 200o, 46.

${ }^{53}$ Cf. Hirstein 2013, 69-7o. 
text undergoes changes when its printing is prepared, that is, both in its development and its publishing.

Rhenanus acquired Rudolf Agricola's translation of Axiochus in Paris, printed in the same city around ${ }_{1502}$. He also had a Basel edition, printed in 1518 in the office of Adam Petri, which closely matches the book that Rhenanus possessed in his personal library. Both publications, in in- $4^{\circ}$, at the beginning of the title page, state the book's skopos: "Axiochus by Plato on the contempt of death" (Axiochus Platonis de contemnenda morte). The Paris edition includes the following poem in two elegiac couplets:

Infracto ut possis animo contemnere mortem,

Ad nomen cuius uulgus inane tremit,

Diuni Socratis uerba haec lege quis morientem

Axiochum monuit, ilico tutus eris.

Rhenanus, who owned five editions of this work - three of Ficino's Latin ver$\operatorname{sion}^{54}$ and two by his favourite translator, Agricola ${ }^{55}$ - meticulously examined the text of the Parisian edition and proposed the amendments and changes that would appear in the Basel edition: capital letters in the proper names, especially those that appear in the myth of Gobryas, punctuation marks - replacing colons with commas - pagination and more spaced typography, resulting in the 8 pages of the Paris edition being extended to the 15 pages of the Basel edition. In this way, in its revision and correction, the Alsatian humanist attempted to champion Agricola's translation over that of Ficino.

Therefore, Rhenanus revised and corrected the text of the dialogue in the Paris edition to improve the book printed in Adam Petri's office in Basel. From his work, the links between proofreader and editor were strengthened. The publishing house had enormous freedom when it came to reprinting a book, which allowed the distribution of a text, such as the pseudo-Platonic dialogue Axiochus, in a European region: in the Upper Rhine of the first decade of the 16th century or, as we have seen previously, in the Castile of the second half of the $15^{\text {th. }}$

${ }^{54}$ The three copies of Marsilio Ficino's translation are the following: the Venice edition, 1497, in Aldo Manuzio's office (BHS K 1041a/WJ 265); the incunabula of Paris, probably published in 1498 in Guy Marchant's office (BHS K 984g/WJ 683. WJ); and the one published in Strasbourg, in Johann's workshop, in 1507 (BHS K 1072a/WJ 1320).

${ }^{55}$ The two editions with translation by Rudolf Agricola: the Paris exemplar, which appeared in 1501 or 1502, in the office of Alexandre Aliate (for Jodocus Badius) (BHS K 822e/WJ 2044); and the one printed in Antwerp by Dirk Martens' press, in 1511 (BHS K $1182 \mathrm{c} / \mathrm{WJ} 556)$. 


\section{Conclusions}

Axiochus, a pseudo-Platonic dialogue devoted to the contempt of death and immortality of the soul, is one of the most popular and well-known texts by Plato between the end of the Middle Ages and the Renaissance. ${ }^{56}$ In 1518 , at least two editions of this dialogue were published in Basel, one in the office of Andreas Cratander and Servatius Ruftanus, and the other in that of Adam Petri. To prepare the latter, Beatus Rhenanus carefully revised and corrected Rudolf Agricola's Latin translation, of which he had two copies, published in Paris (1501 or 1502) and Antwerp (1511). The wealth of the collections in his library and his experience as a philologist and proofreader are reflected in this carefully prepared edition.

The work was previously translated into Spanish around Christmas 1444 by Pedro Díaz de Toledo, intermediary between King Juan II of Castile and Íñigo López de Mendoza, Lord de la Vega, who, after the decisive battle of Olmedo in 1445, would be named Marquis of Santillana. After this work, he devoted himself to the translation of Phaedo. Axiochus, at that time considered authentic, was rendered into Spanish from the Latin translation produced by Cencio de' Rustici eight years earlier.

The author of this apocryphal dialogue, falsely attributed to Plato, could be an academic from the first century BC. Its composition connects with the "consolation" genre, incorporating Stoic, Epicurean and Neo-Pythagorean elements that adhere to both its argumentation and style, in which narration, dialogue and myth are interwoven. Thus, Socrates puts forward a series of arguments to try to convince the dying Axiochus to resign himself and, at the same time, desire death. Adopting a thesis attributed to Prodicus, Socrates points out that the living should not fear death, because they still exist; nor should the dead, because, as they do not exist, they feel nothing. He only manages to comfort Axiochus, however, when he speaks of the immortality of the soul and, by means of a myth, describes the Orphic and Neo-Pythagorean nature of the delights of the future life that await the righteous and the torments that await the unjust.

\footnotetext{
${ }^{56}$ To the aforementioned Latin and Spanish translations, it is necessary to add certain French adaptations and versions that were widely disseminated from the middle of the 16th century, such as that by Étienne Dolet, Le second enfer d'Estienne Dolet [...] suivi de deux dialogues de Platon, l'ung intitulé Axiochus... item ung aultre intitulé Hipparchus... le tout nouvellement traduict en langue françoyse, Lyon, [Dolet.], 1544; and Du Contempnement de la mort. Le livre nommé l'Axiochus de Platon, du contempnement de la mort, en forme de dyalogue, et sont les introduitz Socrates, Clinias et Axiochus, Paris, Denis Janot, s. d.[1545 selon C. Longeon]. See Secret 1966, 109-111; and see also Vega Ramos 2003, 3-4.
} 
While, for Cencio de' Rustici, the interlocutor Axiochus plays a role similar to that of Cardinal Orsini, who died in 1438, Díaz de Toledo planned the structure of the work in his Diálogo e razonamiento en la muerte del Marqués de Santillana after the death of the Spanish nobleman in 1458. For Rhenanus, on the other hand, his revised edition coincides with a doctrinal vindication of Plato against Aristotle, transmitting in his work the influence of Erasmus.

The series of arguments in Axiochus, many of which are compatible with a Christian interpretation, occupied a preferential position among humanists, who interpreted the text as an authentically Platonic dialogue that dealt with the theme of contemnenda morte. The immortal soul, enclosed in a mortal body, wishes to move to its heavenly abode, and the abandonment of this world involves detachment from perishable misfortunes to achieve a lasting happiness forever.

\section{REFERENCES}

Avril, F., Aniel, J.-P., Mentré, M., Saulnier, A., Zaluska, Y. (1983) Manuscrits enluminés de la péninsule ibérique. Paris.

Beghini, A. (2016) "Sul Cinosarge dell'Assioco," in: M. Tulli, ed. Testo e forme del testo. Ricerche difilologia filosofica. Pisa/Roma, 3-34.

Beghini, A. (2017) "Two Textual Notes on the Axiochus ([Plat.] Ax. $364 b_{5}$ and 367a1)," Rheinisches Museum für Philologie 160, 262-275.

Belli, A. (1954) "Le versioni umanistiche dell' Assioco pseudoplatonico," La parola del passato 39, 442-467.

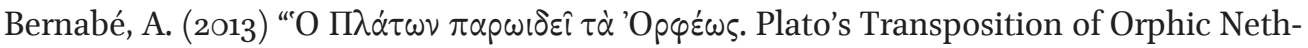
erworld Imagery," in: V. Adluri, ed. Philosophy and Salvation in Greek Religion. Berlin/Boston, 117-149.

Blüher, K. A. (1969) Séneca en España. Investigaciones sobre la recepción de Séneca en España desde el siglo XIII hasta el siglo XVII: Fundamentos y condiciones para la revitalización. Madrid.

Burnet, J., ed. (1900-1907) Platonis Opera, 5 vols. Oxford.

Celenza, C. S. (2007) “The Revival of Platonic Philosophy," in: J. Hankins, ed. The Cambridge Companion to Renaissance Philosophy. Cambridge, 72-96.

Cherchi, P. (1992) "Pero Díaz de Toledo y su Diálogo e razonamiento en la muerte del Marqués de Santillana," in: J. L. Canet Vallés, R. Beltrán Llavador, J. L. Sirera, eds. Historias y ficciones: coloquio sobre la literatura del siglo XV: actas del coloquio internacional. Valencia, 111-120.

Diu, I. (2008) "Du modèle idéal de la bibliothèque humaniste à sa réalisation effective: Érasme et Beatus Rhenanus," Littératures classiques 66, 39-52.

Döring, K., Erler, M., Schorn, S. eds. (2005) Pseudoplatonica. Akten des Kongresses zu den Pseudoplatonica vom 6.-9. Juli 2003 in Bamberg. Stuttgart. 
Dorion, L.-A. (2009) "Prodicos de Céos (environ 470-39o av. J.-C.). Présentation, traduction et notes," in: J.-F. Pradeau, ed. Les sophistes: fragments et témoignages. Vol. I, De Protagoras à Critias. Paris, 343-372, and 525-539.

Erler, M. (2005) "Argumente, die Seele erreichen. Der Axiochos und ein antiker Streit über den Zweck philosophischer Argumente," in: K. Döring, M. Erler, S. Schorn, eds. (2005) Pseudoplatonica. Akten des Kongresses zu den Pseudoplatonica vom 6.9. Juli 2003 in Bamberg. Stuttgart, 81-95.

Erler, M. (2012) "Zur literarisch-philosophischen Einordnung des Dialogs," in: I. Männlein-Robert, O. Schelske, M. Erler, R. Feldmeier, S. Grosse, A. Lohmar, H.-G. Nesselrath, U. Poplutz, eds. (2012) Ps.-Platon: Über den Tod. Tübingen, 99-116.

Faye, E. (1995) "Beatus Rhenanus lecteur et étudiant de Charles de Bovelles," Annuaire des Amis de la Bibliothèque humaniste de Sélesta 45, 119-138.

Faye, E. (1998) "Nicolas de Cues et Charles de Bovelles dans le manuscrit Exigua pluvia de Beatus Rhenanus," Archives d'histoire doctrinale et littéraire du Moyen Age 65, 415-450.

Faye, E. (2000) "Beatus Rhenanus lecteur de Platon et d'Aristote à Paris (1503-1507)," in: J. Hirstein, ed. (2000) Beatus Rhenanus (1485-1547), lecteur et éditeur des textes anciens. Actes du Colloque International tenu à Strasbourg et à Sélestat du 13 au 15 novembre 1998. Turnhout, 33-48.

Faye, E., Ancey, M. (1995) "Le Cours de Métaphysique de 1504 pris en note par Beatus Rhenanus au Collège du Cardinal Lemoine: Edition et traduction des propositions 1 à 3," Annuaire de la Société des Amis de la Bibliothèque Humaniste de Sélestat 45, 139-142.

Fernandes, E. (2016) "El Fedón y la Educación para la (no-)muerte en la España Quinientista," Archai 17, 57-93.

González Rolán, T., Saquero Suárez-Somonte, P. (200o) "El Axíoco pseudo-platónico traducido e imitado en la Castilla de mediados del siglo XV: Edición y estudio de la versión romance de Pedro Díaz de Toledo y de su modelo latino," Cuadernos de Filología Clásica: Estudios Latinos 19, 157-197.

González Rolán, T., Moreno Hernández, A., Saquero Suárez-Somonte, P. (2000) Humanismo y teoría de la traducción en España e Italia en la primera mitad del siglo $X V$. Edición y estudio de la Controversia Alphonsiana (Alfonso de Cartagena vs. L. Bruniy P. Candido Decembrio). Madrid.

Grespi, G. (2005) Traducciones castellanas de obras latinas e italianas contenidas en manuscritos del siglo XV en las bibliotecas de Madrid y El Escorial. Madrid.

Hankins, J. (1990) Plato in the Italian Renaissance, 2 vols. Leiden/New York.

Herrero Prado, J. L. (1998) "Pero Díaz de Toledo, Señor de Olmedilla," Revista de Literatura Medieval 10, 101-115.

Hershbell, J. P. (1981) Pseudo-Plato, Axiochus. Chico.

Hirstein, J. ed. (2000) Beatus Rhenanus (1485-1547), lecteur et éditeur des textes anciens. Actes du Colloque International tenu à Strasbourg et à Sélestat du 13 au 15 novembre 1998. Turnhout. 
Hirstein, J. (2013) "Une Druckvorlage de la bibliothèque de Beatus Rhenanus et la diffusion de la pensée néo-platonicienne dans le Rhin Supérieur: l'Axiochus du Pseudo-Plato," in: C. Maurer, A. Starck-Adler, C. Weeda, eds. L'espace rhénan, pôle de savoirs. Strasbourg, 51-76.

Horawitz, A., Hartfelder, K. (1886) Briefwechsel des Beatus Rhenanus. Leipzig.

Joyal, M. (2005) "Socrates as бoфòs àvíp in the Axiochus," in: K. Döring, M. Erler, S. Schorn, eds. (2005) Pseudoplatonica. Akten des Kongresses zu den Pseudoplatonica vom 6.-9. Juli 2003 in Bamberg. Stuttgart, 97-117.

Kerferd, G. B., Flashar, H. (1998) "Die Sophistik," in: H. Flashar, ed. Grundriss der Geschichte der Philosophie. Die Philosophie der Antike. Band 2/1: Sophistik - Sokrates - Sokratik - Mathematik - Medizin. Basel.

Männlein-Robert, I., Schelske, O., Erler, M., Feldmeier, R., Grosse, S., Lohmar, H.-G. Nesselrath, U. Poplutz, U. eds. (2012) Ps.-Platon: Über den Tod. Tübingen.

Meyer, H. (1976) "Beatus Rhenanus (de Sélestat) et sa bibliothèque," Librarium: Zeitschrift der Schweizerischen Bibliophilen Gesellschaft 19, 21-31.

Meyer, H., Petitmengin, P. (1985) "Ex libris Beati Rhenani: Les imprimés qui ont quitté la Bibliothèque de Sélestat depuis le milieu du XVIIIe siècle," Annuaire des Amis de la Bibliothèque humaniste de Sélestat 35, 123-133.

Moreau, B. (1972) Inventaire chronologique des éditions parisiennes du XVIe siècle. Vol. I. Paris.

Morel-Fatio, A. (1892) Catalogue des manuscrits espagnols et des manuscrits portugais. Paris.

Orcajo, T. R. (1929) Catalogo descriptivo de los códices que se conservan en la santa iglesia catedral de Burgo de Osma. Madrid.

Paz y Meliá, A. (1982) Opúsculos Literarios de los Siglos XIV á XVI. Madrid.

Petitmengin, P. (1989) "Les Livres de Beatus Rhenanus," in: A. Vernet, ed. Histoire des bibliothèques françaises, Vol. I: Les bibliothèques médiévales du $\mathrm{VI}^{\mathrm{e}}$ siècle à $153 \mathrm{O}$. Paris: $298-301$.

Riss, B. A. (1985) Pedro Díaz de Toledo's Proverbios de Séneca: and Annotated Edition of MS. S-II-1o of the Escorial Library. Ann Arbor.

Roldán Donoso, C. (2015) "La intervención del impresor sobre la obra: Pedro Hagenbach y su edición de los Proverbios de Séneca (Toledo 1500)," Revista de Estudios Latinos $15,113-140$.

Round, N. G. (1972) "The Mediaeval Reputation of the Proverbia Senecae: A Partial Survey Based on Recorded MSS," Proceedings of the Royal Irish Academy. Section C: Archaeology, Celtic Studies, History, Linguistics, Literature 72, 103-151.

Round, N. G. (1993) Libro Llamado Fedrón: Plato's Phaedo Translated by Pero Diaz de Toledo (Ms Madrid, Biblioteca Nacional Vitr 17, 4). London/Madrid.

Saffrey, H. D. (1971) "Un humaniste dominicain, Jean Cuno de Nuremberg, précurseur d'Erasme à Bâle," Bibliothèque d'Humanisme et de Renaissance 33, 19-62.

Sanz Fuentes, M. J. (2014) "El testamento de Fernán Díaz de Toledo, el relator (1455)," Historia, Instituciones, Documentos 41, 381-406. 
Secret, F. (1966) "La traduction de l'Axiochus par G. Postel," Bibliothèque d'Humanisme et Renaissance 28, 109-111.

Trapp, M. B. (2000) "Beatus Rhenanus and Maximus of Tyre (Basel, 1519)," in: J. Hirstein, ed. (2000) Beatus Rhenanus (1485-1547), lecteur et éditeur des textes anciens. Actes du Colloque International tenu à Strasbourg et à Sélestat du 13 au 15 novembre 1998. Turnhout, 151-171.

Tulli, M. (2005) "Der Axiochos und die Tradition der consolatio in der Akademie," in: K. Döring, M. Erler, S. Schorn, eds. (2005) Pseudoplatonica. Akten des Kongresses zu den Pseudoplatonica vom 6.-9. Juli 2003 in Bamberg. Stuttgart, 255-271.

Vega Ramos, M. J. (2003) "Miseria y dignidad del hombre en el Renacimiento: de Petrarca a Pérez de Oliva," Ínsula: revista de letras y ciencias humanas 674, 6-9.

Villacañas Berlanga, J. L. (2010) "Platón en la Castilla premoderna. La visión de Nicholas Round," Biblioteca Saavedra Fajardo de Pensamiento Político Hispánico 129, 1-16.

Walter, J. (1929) Catalogue général de la Bibliothèque municipale. Première série, Les livres imprimés. Troisième partie, Incunables \& XVIme siècle. Colmar.

Zehnacker, F. (1997) Catalogues régionaux des incunables des bibliothèques publiques de France. Vol. XIII: Région Alsace (Bas-Rhin). Paris. 